\title{
On the verge of extinction in Mexico today: Field observations of Ambystoma ordinarium and Ambystoma flavipiperatum with remarks on their habitat and conservation
}

\author{
AXEL HERNANDEZ ${ }^{1 *}$, JEAN RAFFAËLLI ${ }^{2}$, EMMANUEL JELSCH ${ }^{3}$, VERÓNICA CAROLINA ROSAS- \\ ESPINOZA ${ }^{4}$, ANA LUISA SANTIAGO-PÉREZ ${ }^{4} \&$ PABLO BEREA NUNEZ ${ }^{5,6}$
}

\author{
${ }^{1}$ Department of Environmental Sciences, Faculty of Sciences and Technics, University Pasquale Paoli of Corsica, Corte, 20250, France \\ ${ }^{2}$ Penclen, Plumelec, 56420, France \\ ${ }^{3}$ Chemin du Verney 12, CH-1185 Mont-sur-Rolle, Switzerland \\ ${ }^{4}$ Universidad de Guadalajara, Centro Universitario de Ciencias Biológicas y Agropecuarias, Camino Ing. Ramón Padilla Sánchez \\ No. 2100, Nextipac, Zapopan, Jalisco, México, C.P.45200 \\ ${ }^{5}$ Universidad del Medio Ambiente en Valle de Bravo, Estado de México \\ ${ }^{6}$ Octolab, Camino a Manantial No.3, Xalapa, 91060, Veracruz, México \\ *Corresponding author e-mail: hernandez.axel.1989@gmail.com
}

\begin{abstract}
Mexico is a hotspot of salamander diversity and harbours 18 species of the genus Ambystoma (Amphibia: Urodela) widely distributed from the Sierra Madre Occidental to the Trans-Mexican Volcanic Belt. These species are highly threatened by various factors and some of them are considered nearly extinct in the wild. The Michoacán stream salamander, Ambystoma ordinarium and the yellow-peppered salamander, A. flavipiperatum are two endemic and scarce species from Mexico living in isolated and declining populations. Few observations have been made on them in their natural habitat since their original description. Here we report new data regarding the biology and habitats of A. ordinarium observed at Rio Bello, 2,120 m a.s.l., Morelia city, Michoacán state, and for A. flavipiperatum at Sierra de Quila, 2,165 m a.s.l., 100 km south from Guadalajara city, Jalisco state. For $A$. ordinarium we found one neotenic adult male and two dead adult females in a small shallow stream located within a fragmented fir, oak and pine forest. For $A$. flavipiperatum we recorded an adult male and a female both neotenic, one clutch of eggs, and eleven larvae inhabiting a slow-moving stream located through a riparian habitat surrounded by large pineoak forest. Our observations confirm that both species are highly endangered, capable of facultative neoteny and occur in small slow-moving streams surrounded by coniferous forests. We discuss their morphology, geographical distribution and conservation status.
\end{abstract}

\section{INTRODUCTION}

$\mathrm{M}$ exico is a hotspot of salamander diversity (Petranka, 1998; AmphibiaWeb, 2019) and harbours 18 species of the genus Ambystoma widely distributed from the Sierra Madre Occidental to the Trans-Mexican Volcanic Belt (Raffaëlli, 2013; Percino-Daniel et al., 2016; AmphibiaWeb, 2019). These species generally breed in deep volcanic lakes, shallow vernal pools, artificial cattle ponds, and intermittent, fish-free stream pools. Their habitat is mainly associated with temperate climates at high altitudes while Ambystoma velasci is the only species that may sometimes be found in arid and semi-arid habitats (Raffaëlli, 2013). Here we report on field observations of two species the Michoacán stream salamander, A. ordinarium Taylor, 1940 and the yellowpeppered salamander, A. flavipiperatum Dixon, 1963.

Ambystoma ordinarium is a polymorphic species native to the central part of the Trans-Mexican Volcanic Belt in the vicinity of Lake Patzcuaro in Michoacán state up to Tianguistenco, Western Mexico state (Anderson \& Worthington, 1971; Anderson, 1975). It occurs at high elevation (1,400-3,000 $\mathrm{m}$ a.s.I.) in mountainous habitats (Anderson \& Worthington, 1971; Weisrock et al., 2006;
Escalera-Vasquez et al., 2018). Both larvae and neotenic individuals inhabit high mountain brooks or spring pools at the headwaters of streams (Anderson \& Worthington, 1971). Metamorphosed adults can be found hiding under debris in coniferous forests as far as $30 \mathrm{~m}$ from streams (Alvarado-Diaz et al., 2003).

By contrast, A. flavipiperatum Dixon, 1963 is a robust salamander that occurs at two sites around Guadalajara city, Santa Cruz, approximately $41.8 \mathrm{~km}$ south-west of Guadalajara at an elevation of $1,494 \mathrm{~m}$ a.s.l. (Dixon, 1963) which is the type-locality, and within the Sierra de Quila, Jalisco state, west-central Mexico between 1,494-2,400 m a.s.I (SantiagoPérez et al., 2012; Raffaëlli, 2013; Rosas-Espinoza et al., 2013; Ahumada-Carrillo et al., 2014; Cortés-Vázquez et al., 2016; Cruz-Sáenz et al., 2017). These two Ambystoma species are classified Endangered according to IUCN and protected by Mexican laws (NOM-059-SEMARNAT-2010; IUCN, 2015, 2016; Cortés-Vázquez et al., 2016; AmphibiaWeb, 2019). To date, there have been few observations of this species in its natural habitat. Here we report new field observations and we discuss morphology, geographical distribution and conservation status. 


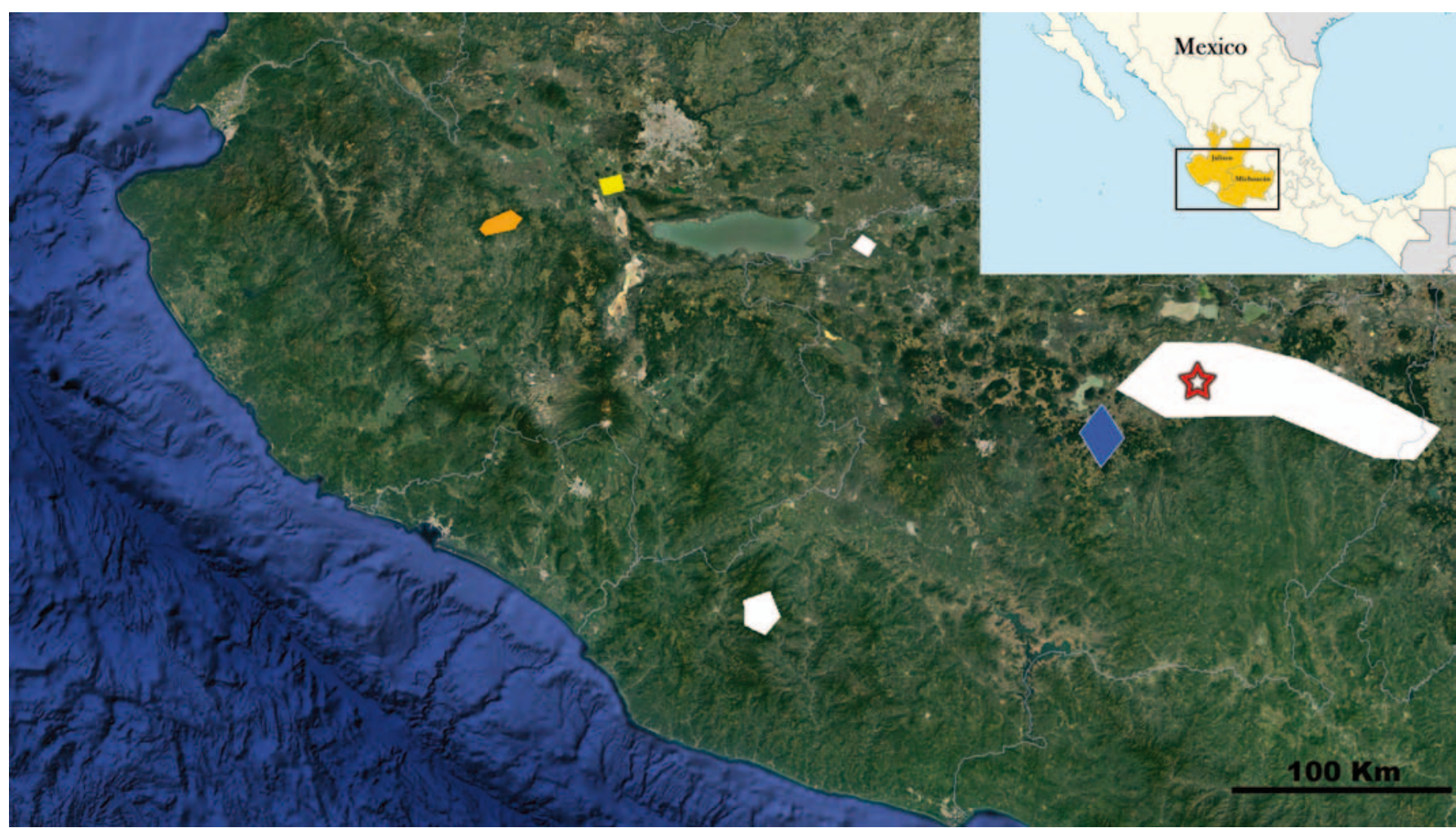

Figure 1. A map of Mexico showing the main distribution of A. ordinarium and A. flavipiperatum. White area: A. ordinarium; red star: Rio Bello (this study); blue area: A. ordinarium sp.; Yellow area: A. flavipiperatum type locality; Orange area: Sierra de Quila (this study)

\section{METHODS}

\section{Study sites}

We conducted field work during the rainy season (July to August) in 2013 and in 2018 in the states of Jalisco and Michoacán, north-western Mexico (Fig. 1). A total of three specimens of Ambystoma ordinarium were found at Rio Bello $\left(19^{\circ} 40^{\prime} 38.3^{\prime \prime} \mathrm{N}, 101^{\circ} 8^{\prime} 47.5^{\prime \prime} \mathrm{W}\right)$ at 2,120 $\mathrm{m}$ a.s.l. in the vicinity of Morelia city, Michoacán state, Mexico on 13 August 2018. One neotenic adult female, one neotenic adult male, one clutch of eggs and eleven larvae of $A$. flavipiperatum were observed during daytime at Sierra de Quila $\left(20^{\circ} 17^{\prime} 56^{\prime \prime} \mathrm{N}\right.$, $104^{\circ} 1^{\prime} 5.999^{\prime \prime}$ W) at 2,165 m a.s.I., Jalisco state, Mexico on 1 August 2018. By the Koppen classification the climate of both sites is rated 'subtropical highland'(Cwb).

\section{Field survey}

The Visual Encounter Survey (VES) was used to search for the axolotls, a method that is cost effective and does not disturb habitats of endangered or sensitive species (Heyer et al., 1994). Survey sites were selected based on historical published records and by studying local maps showing available water for the target species at the vicinity of forested areas (Anderson \& Worthington, 1971; Anderson, 1975; Alvarado-Diaz et al., 2003; Weisrock et al., 2006; RosasEspinoza et al., 2013; Ahumada-Carrillo et al., 2014; CortésVázquez et al., 2016; Cruz-Sáenz et al., 2017; Soto-Rojas et al., 2017; Escalera-Vasquez et al., 2018). Everyday field work was undertaken from about 09:00h to 12:30h. Observations of vegetation and habitats were made on field trips, both on sunny and on rainy days. We have surveyed almost all types of habitat including permanent and temporary streams but also ponds (including artificial reservoirs and irrigation canals), and surrounding terrestrial habitats, stumps, stones and leaf litter.

We photographed each taxon observed including plant and tree species for identification (Sony Nex-5; Sony Ltd., Japan). Coordinates, geographic and elevational data were collected in situ using a GPS (Garmin Montana 680; Garmin Ltd., Olahe, KS, USA) and located on maps. The temperature, $\mathrm{pH}$ and dissolved ions in water were measured in situ using a Expresstech @ LCD pH Medidor Digital (Expresstech, Kingpow Company Limited, Hong-Kong, China).

\section{Morphology}

Morphological measurements were made to the nearest 0.1 $\mathrm{mm}$ with a dial caliper (Louisware LSWCL1810, Louisware Ltd., USA). Data for comparisons were obtained from the original description provided by Taylor (1940) and Dixon (1963). When handling the axolotls we wore disposable vinyl gloves that had been rinsed with distilled or sterilised water. These gloves were changed between animals to prevent any cross-contamination. All animals were then released at the exact place of capture for conservation purposes following national and international ethical standards (NOM-059SEMARNAT-2010; IUCN, 2015, 2016).

\section{RESULTS}

On 13 August 2018, A. ordinarium was recorded at Rio Bello $\left(19^{\circ} 40^{\prime} 38.3^{\prime \prime} \mathrm{N}, 101^{\circ} 8^{\prime} 47.5^{\prime \prime} \mathrm{W}\right)$ at 2,120 $\mathrm{m}$ a.s.l. in the vicinity of Morelia city, Michoacán state, Mexico. We observed one neotenic adult male (Fig. 2A) in a small shallow stream located within a fragmented fir, oak and pine forest composed of 
Table 1. Number of costal grooves and morphological measurements $(\mathrm{mm})$ for $\mathrm{A}$. ordinarium and A. flavipiperatum

\begin{tabular}{|l|c|c|c|c|c|c|c|c|c|c|c|}
\hline Species & Gender & $\begin{array}{c}\text { No. costal } \\
\text { grooves }(\mathbf{n})\end{array}$ & TL & SVL & HW & HL & IOW & IEW & FL & HLL & GL \\
\hline Ambystoma ordinarium & Male & 13 & 131 & 58.7 & 15.4 & 18.2 & 5.5 & 4.5 & 12.6 & 18.9 & 11.8 \\
A. flavipiperatum & Male & 13 & 141 & 66.7 & 16.6 & 22.8 & 7.8 & 6.5 & 22.5 & 25.9 & 15.8 \\
& Female & 12 & 171 & 89.1 & 19.1 & 24.9 & 8.9 & 7.7 & 28.0 & 32.1 & 21.1 \\
\hline
\end{tabular}

$\mathrm{TL}$ - total length, SVL - snout vent length, HW - head width, HL - head length, IOW- interorbital width, IEW - internarial width, FL - forelimb length, $\mathrm{HLL}$ - hindlimb length , GL -gill length

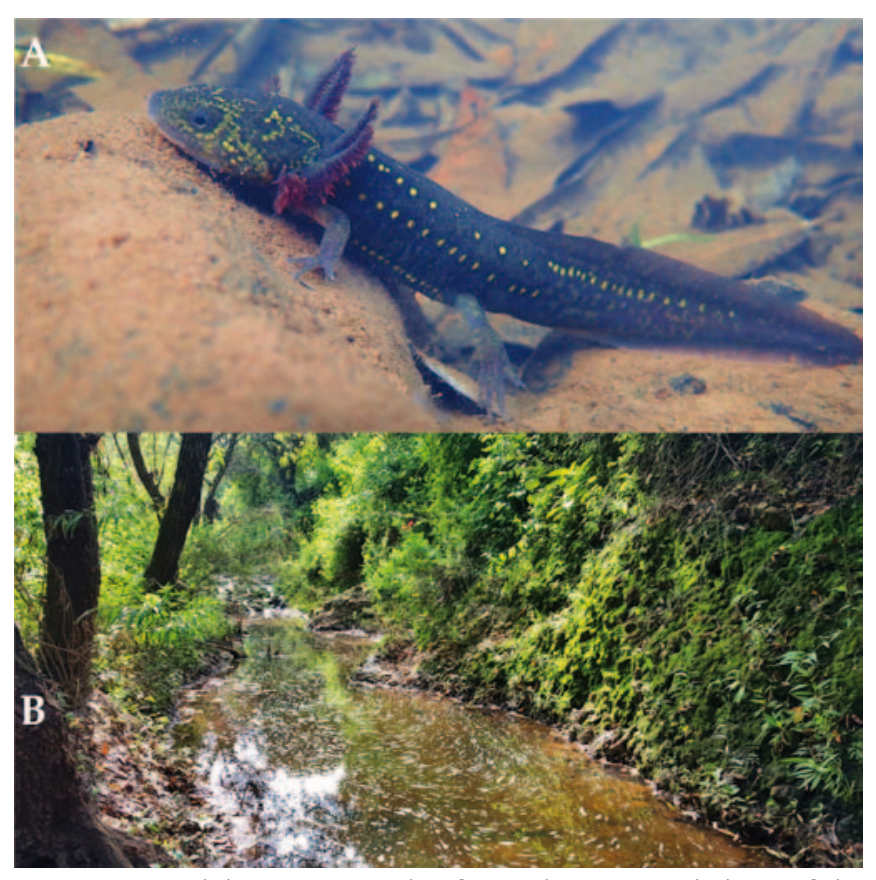

Figure 2. A. adult neotenic male of $A$. ordinarium, B. habitat of the target species at Rio Bello, Michoacán, Mexico

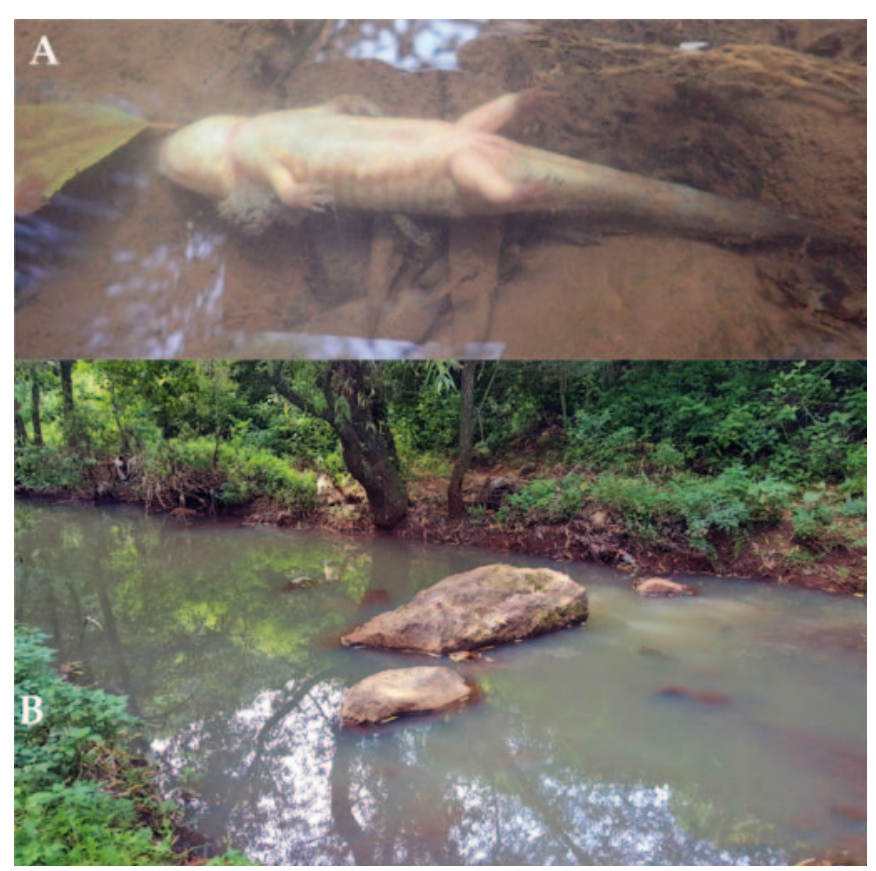

Figure 3. A. one dead adult female of $A$. ordinarium, B. picture showing degradation and flow changing of the main stream where the species was previously known to occur at Rio Bello. Dead specimens were found in the vicinity of this site.
Abies religiosa, Pinus leiophylla, Pinus michoacana, Quercus castanea, Quercus crassifolia, and partially some subtropical shrubs such as Acacia farnesiana, Acacia pennatula, Eysenhardtia polystachya, and Ipomoea arborescens (Fig. 2B). At the time the air temperature was $22.9-26.7{ }^{\circ} \mathrm{C}$ and water temperature $19.0-19.2^{\circ} \mathrm{C}$. The stream had a rocky substrate and the water quality was slightly alkaline $(\mathrm{pH}$ 7.92-8.06) with dissolved ions between 301-306 mV. The specimen was confirmed as male by the presence of a rounded cloaca. The number of costal grooves and physical dimensions of this specimen are shown in Table 1. Its general coloration was black with small yellow spots on the dorsal and ventral surfaces. Gills were prominent beside the head and had a reddish purple hue. We also photographed two dead females within the same stream $600 \mathrm{~m}$ below a road under construction (Fig. $3 A$ \& 5B). We noticed the presence of a dam nearby that may have affected the flow and quality of the stream water (Fig. 3B). This suggests that the development of Morelia city is having a negative impact on the habitat of $A$. ordinarium.

During daytime on 1 August 2018, we found $A$. flavipiperatum inhabiting a coniferous forest at Sierra de Quila $\left(20^{\circ} 17^{\prime} 56^{\prime \prime} \mathrm{N}, 104^{\circ} 1^{\prime} 5.999^{\prime \prime} \mathrm{W}\right)$ at 2,165 m a.s.l., Guadalajara, Jalisco state, Mexico. The observations included one neotenic adult female (Fig. 4A), one neotenic adult male, one clutch of eggs and eleven larvae (Fig. 4B) all found in one slow-moving stream located through a riparian habitat (Fig. 5A) composed of Alnus acuminata, Pinus douglasiana, Salix bonplandiana, Prunus serotina ssp. capuli and ferns including mainly Cheilanthes spp., Asplenium spp. and surrounded by large pine-oak forest composed of $P$. douglasiana, P. oocarpa and Quercus resinosa. At the time the air temperature was 19.6-22.4 ${ }^{\circ} \mathrm{C}$ and water temperature $16.4-18.3{ }^{\circ} \mathrm{C}$. The stream had a rocky-sandy including various rocks, fallen leaves, tree roots and decomposing debris in decomposition. The water quality was about neutral ( $\mathrm{pH}$ 6.96-7.21) with dissolved ions between $401-410 \mathrm{mV}$. Adult individuals were neotenic specimens observed on the bottom of the largest parts of the stream at a water depth of $65-70 \mathrm{~cm}$. The number of costal grooves and physical dimensions of the male and female specimens are shown in Table 1 . The female had same coloration as the male but larger longitudinal white bands on the ventral surfaces. A total of 120-140 eggs were observed beside a female, attached to submerged tree roots on the bottom of this stream at a depth of 40$65 \mathrm{~cm}$. The eggs ranged from 1.7 to $2.0 \mathrm{~mm}$ in diameter. The larvae were hidden under fallen leaves, within debris or under the banks of the river. When disturbed, they hid 
quickly in dark refuges. Their total length was 17-62 mm, dorsally they were generally coloured dark-brown to black, while ventrally they tended to be clearer with a whitish appearance. Larger individuals $(45-62 \mathrm{~mm}$ ) had very small white to yellowish spots (Fig. 4B).

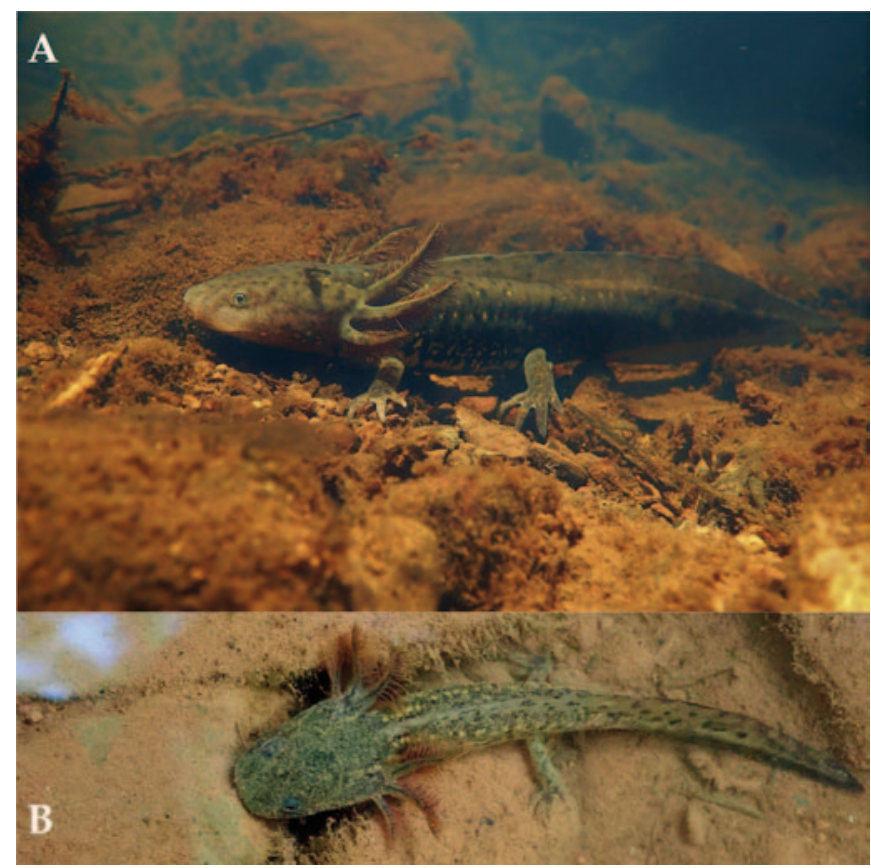

Figure 4. A. Adult neotenic female of $A$. flavipiperatum observed at Sierra de Quila, B. Larva of A. flavipiperatum at the same prospected site

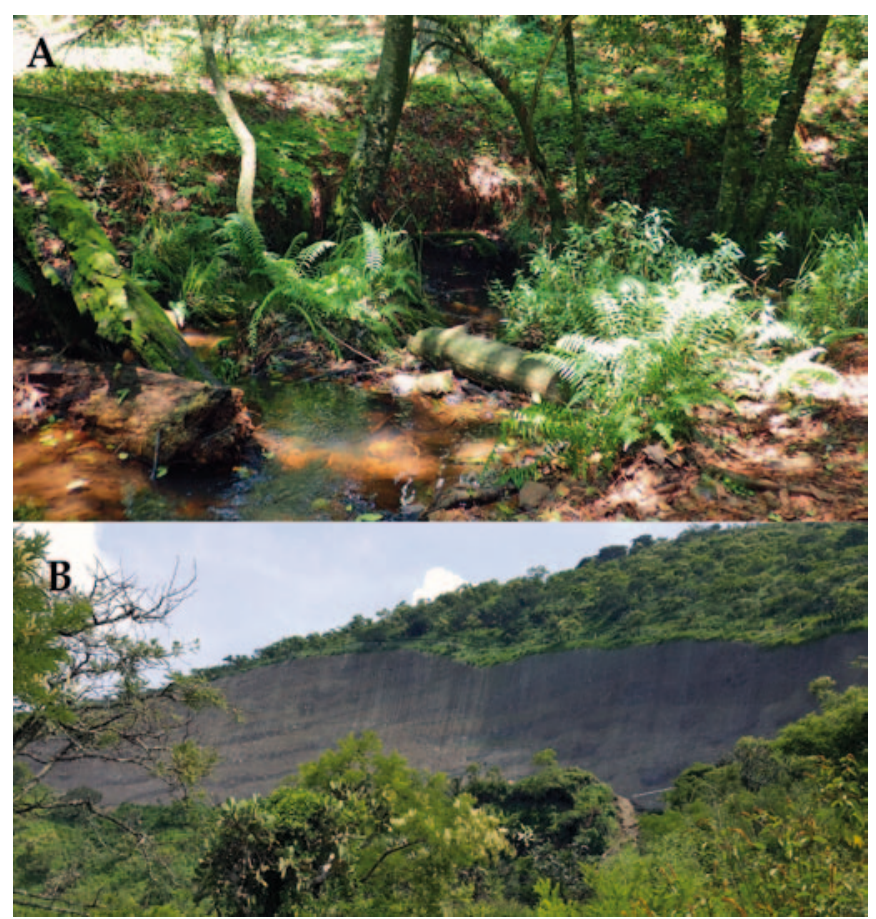

Figure 5. A. Microhabitat view of $A$. flavipiperatum at Sierra de Quila, B. Degradation of the main habitat of $A$. ordinarium at Rio Bello due to a road construction

\section{DISCUSSION}

Our observations confirm that both endemic species. A. ordinarium and $A$. flavipiperatum have the potential for facultative neoteny and that probably they are composed of small-numbered populations. Both inhabit small slowmoving streams surrounded by coniferous forests at Rio Bello and within the Sierra de Quila, altogether located within the Trans-Mexican Volcanic Belt, Mexico. However, the Santa Cruz type locality of $A$. flavipiperatum was a different habitat type, characterised by thorn forests including desert scrub vegetation with rocky soil and a multitude of rock outcroppings (Dixon, 1963).

Concerning morphology, our specimens of $A$. ordinarium conformed to the original description provided by Taylor (1940) and additional studies (Duellman, 1961; Anderson \& Worthington, 1971). This salamander measures between 70 and $75 \mathrm{~mm}$ SVL at sexual maturity, reaching a maximum size of $86 \mathrm{~mm}$ SVL for terrestrial adults up to a maximum size of 191 in TL (Raffaëlli, 2013; AmphibiaWeb, 2019). A. ordinarium has a narrow head, and generally bears 16-24 tooth-rakers on the $3 \mathrm{rd}$ arch. Adults have a uniformly dark to black dorsum, but mottling may also be present with small yellow spots. Some adults retain the larval coloration, consisting of slight ventral, lateral, and dorsal rows of light silver-yellow specks from axilla to groin (Anderson \& Worthington, 1971; Shaffer, 1984a,b). Dorsal patterns and colour may vary between specimens and populations (pers. obs.).

At Rio Bello, all specimens were found in water and were facultative neotenics with long reddish gills. According to Alavarado-Diaz et al. (2012), A. ordinarium inhabits high mountain brooks or spring pools at the headwaters of streams, with water temperatures remaining between 11.8 and $12.4{ }^{\circ} \mathrm{C}$. Metamorphosed adults can be found hiding under debris in coniferous forests as far as $30 \mathrm{~m}$ from streams (Alavarado-Diaz et al., 2002).

Ambystoma flavipiperatum from Sierra de Quila is quite different from the original description by Dixon (1963). Dixon found four metamorphosed specimens in Santa Cruz, while we only observed neotenic individuals in the Sierra de Quila as previously reported (Santiago-Pérez et al., 2012; Rosas-Espinoza et al., 2013; Ahumada-Carrillo et al., 2014; Cortés-Vázquez et al., 2016; Cruz-Sáenz et al., 2017). However, some terrestrial adults are known to move through riparian zones in the vicinity of streams, especially in hidden burrows constructed by Buller's pocket gophers (Pappogeomys bulleri) probably seeking protection from dehydration and potential predators (Rosas-Espinoza et al., 2014). Thus, the species shows facultative neoteny at Sierra de Quila while metamorphosed individuals are fossorial as is well known in all other terrestrial ambystomatids (Petranka, 1998).

According to the original description of $A$. flavipiperatum, the male holotype has a snout-vent length of $99.5 \mathrm{~mm}$ and a total length of $175.0 \mathrm{~mm}$ while the three females ranged from 80.0-103.0 $\mathrm{mm}$ in snout-vent length and 137.0-188.0 in total length. The head is longer than wide, with the length being a quarter of the snout-vent length and the width being a fifth of the snout-vent length. The internarial width is slightly more than 1.5 times the length of the eye. However, the nostrils are only about one eye length from the eye. There is a shallow groove starting from the posterior of the eye and leading to the angle of the jaw (Dixon, 1963). 
At Sierra de Quila, two neotenic specimens including one male and one female of $A$. flavipiperatum were previously reported (Rosas-Espinoza et al., 2013). They were smaller and measured 173.8 and $154.7 \mathrm{~mm}$ (TL) respectively, and had 12 costal grooves. Coloration was not reported. During our field survey, specimens observed differed by being shorter (141-171 mm in TL; 66.7-89.1 mm in SVL), having 12 to 13 costal grooves and a black general coloration on the dorsal parts with small white cream to yellowish spots. There were also two longitudinal whitish marks present on the ventral parts of the individuals (yellow in the type series; see Dixon, 1963). There are also many white-yellowish spots between the axilla and groin on both sides, and more yellow spots on the lateral sides of the tail. There were also a few large dark spots on the dorsal parts, head or limbs (not reported in Dixon, 1963). In conformity with the first description, adult females had longer tails than males while males had the cloacal region greatly enlarged and rounded (Raffaëlli, 2013).

Dixon reported eggs but not larvae in the original $A$. flavipiperatum description (see Dixon, 1963). He assumed that eggs are similar to those of $A$. rosaceum and that a female can lay 2500 to 3000 eggs in total while he only found 1451 eggs in ovaries of the largest paratype female. At Sierra de Quila, we observed 120-140 eggs arranged at the same place, but separated at the bottom of the stream, near a large female. Moreover, we found eleven larvae of this elusive species (Fig. 4B). Larval stages have not been reported until now. The larvae can be diagnosed by size 17$62 \mathrm{~mm}(\mathrm{TL})$ with a general greyish coloration on the dorsal parts while ventral parts tended to be clearer with a whitish appearance. Gills are long and reddish. Present on the dorsum of larger individuals (45-62 $\mathrm{mm}$ ) were very small white to yellowish spots. These observations extend the original descriptions and also suggest that $A$. flavipiperatum at Sierra de Quila continue to breed at the beginning of August which is confirmed by the finding of eggs and larvae, but our results provide an incomplete diagnosis. New morphological studies are needed to evaluate the biological characteristics of different populations.

The ecology, biology and natural history of $A$. ordinarium and $A$. flavipiperatum are to date poorly known due to the small number of adult individuals observed in their natural habitat (Shaffer, 1989; Raffaëlli, 2013; Raffaëlli \& Hernandez, 2019). Indeed, most of the Ambystoma species are endangered or highly endangered (Escalera-Vasquez et al., 2018; Raffaëlli and Hernandez, 2019). To date both species are both classified Endangered (EN) following the IUCN Red List and are placed under special protection by federal environmental laws (NOM-059-SEMARNAT-2010; IUCN, 2015, 2016).

Observation of two dead adult and neotenic females at Rio Bello reveals that $A$. ordinarium is facing a conservation threat at this site, probably due to a substantial increase in the flow of the main stream and a road construction that is destroying its natural habitat (Fig. 3B \& 5B). In 1999, the species was abundant in several localities occupying a total area of $4,283 \mathrm{~km}^{2}$ but surveys undertaken since 2004 indicated that all populations are very fragmented and declining, with the species disappearing in some localities (IUCN, 2015). In recent years, Soto-Rojas et al. (2017) detected only 16 streams inhabited by $A$. ordinarium despite there being 29 historical records in the last century. Moreover, most of the habitats analyzed contained populations severely affected by various abnormalities caused by water pollution (Soto-Rojas et al., 2017). The conservation outlook appears worse than it might seem as A. ordinarium is considered as a species complex containing at least one undescribed taxon within the western part of its known range, south of Lake Patzcuaro and known from just a few localities (Hime et al., 2016). Consequently, the eastern lineage from the type locality may actually have a range of only $120 \times 20 \mathrm{~km}$.

Ambystoma flavipiperatum is also threatened because its range and occurrence are very limited, showing 134 $\mathrm{km}^{2}$ of occupancy comprising only two localities until now (Raffaëlli, 2013; IUCN, 2016; Amphibiaweb, 2019). Its major threats are habitat destruction and fragmentation from smallholder farming (Rosas-Espinoza et al., 2013; Ahumada-Carrillo et al., 2014; Cortés-Vázquez et al., 2016; Cruz-Sáenz et al., 2017). The species is also threatened by water pollution, road construction, human settlements, and introduction of predatory fish (Raffaëlli, 2013). Even though the Sierra de Quila is a protected area 'Área de Protección de Flora y Fauna Sierra de Quila', water pollution by visitors and climate change, which has affected rainfall patterns and intensity, has caused a reduction in suitable habitat (IUCN, 2016; Villers-Ruiz and Trejo-Vázquez, 2000). To date, a local committee in the Area de Protección de Flora y Fauna Sierra de Quila, is using A. flavipiperatum as an umbrella species to protect clean water (AmphibiaWeb, 2019). Moreover, at Santa Cruz, located $48 \mathrm{~km}$ south from the Guadalajara Metropolitan Area, the species has probably disappeared due to the construction of a shopping mall on the only available wetland and new assessments are needed (Rosas-Espinoza \& Santiago-Pérez pers. com. 2018). Consequently, the population from Sierra de Quila is very important in terms of conservation and needs further assessments including genetic analysis to confirm its status and population viability. It is believed that both species can breed well in captivity (Raffaëlli, 2013) and it is possible that observations in captivity could generate new and important biological and ecological data that could be helpful in the design of conservation programmes (Hernandez, 2017).

Finally, another problem concerns the taxonomic status of many Mexican axolotls. Their taxonomy is uncertain because many species share mitochondrial genes due to recent introgression and also often show low genetic divergence between species (Shaffer \& McKnight, 1996; Weisrock et al., 2006; Escalera-Vasquez et al., 2018). In addition, many isolated populations distributed within the western and northern part of the Trans-Mexican Volcanic Belt have not still not been assessed taxonomically or for their conservation status. Good examples of this are the southern lineage of $A$. rosaceum and populations of Ambystoma velasci from south-western Jalisco and southern Michoacán. In this alarming context, more surveys and analysis are needed to improve the knowledge base and conservation strategies of axolotls which today are on the verge of extinction in Mexico. 


\section{ACKNOWLEDGEMENTS}

We express our particular thanks for help with our studies to David Burton Wake, Manuel Gonzales, University Pasquale Paoli of Corsica, the Autonomous University of Michoacán, University of Guadalajara-CUCBA, and the Association for the Conservation and Sustainable Management of the Sierra de Quila. Thanks also to AmbystoLab and Octolab for providing permits.

\section{REFERENCES}

Ahumada-Carrillo, I.T., Reyna-Bustos, O.F. \& Vázquez-Ruiz, C. (2014). Geographic distribution: Ambystoma flavipiperatum. Herpetological Review 45: 85.

Alvarado-Diaz, J., Garcia-Garrido, P. \& Suazo-Ortuño, I. (2003). Food habits of a paedomorphic population of the Mexican salamander, Ambystoma ordinarium (Caudata: Ambystomatidae). The Southwestern Naturalist 28: 100102.

AmphibiaWeb. (2019). Amphibian Species of the World (ASW) version 5.6. Information on amphibian biology and conservation (web application). Berkeley. California. Available from: http:// amphibiaweb.org.

Anderson, J. D. (1975). Ambystoma ordinarium. Catalogue of American Amphibians and Reptiles. Society for the Study of Amphibians and Reptiles 164.1-164.2.

Anderson, J.D. \& Worthington, R.D. (1971). The life history of the Mexican salamander Ambystoma ordinarium Taylor. Herpetologica 27: 165-176.

Cortés-Vázquez, S., Cruz-Sáenz, D. \& Wilson, L.D. (2016). Notes on a leucistic Ambystoma flavipiperatum Dixon, 1963 (Caudata: Ambystomatidae). Mesoamerican Herpetology 3: 1077-1080.

Cruz-Sáenz, D., Muñoz-Nolasco, F.J., Mata-Silva, V., Johnson, J.D., García-Padilla, E. \& Wilson, L.D. (2017). The herpetofauna of Jalisco, Mexico: composition, distribution, and conservation. Mesoamerican Herpetology 4: 23-118.

Dixon, J.R. (1963). A New Species of Salamander of the Genus Ambystoma from Jalisco, Mexico. Copeia 1963: 99-101.

Duellman, W.E. 1961. The amphibians and reptiles of Michoacán, México. University of Kansas Publications, Museum of Natural History 15: 1-148.

Escalera-Vázquez, L.H., Hernández-Guzmán, R., Soto-Rojas, C. \& Suazo-Ortuño, I. (2018). Predicting Ambystoma ordinarium Habitat in Central Mexico Using Species Distribution Models. Herpetologica 74: 117-126.

Hayer, W.K., Donnelly, M.A., McDiamid, R.W., Hayekand, L.C. \& Foster, M.S. (eds.). (1994). Measuring and Monitoring Biodiversity, standard methods for amphibians. Washington: Smithsonian institution Press. 364 pp.

Hernandez, A. 2017. Successful reproduction of the mole salamander Ambystoma talpoideum in captivity with an emphasis on stimuli environmental determinants. Herpetological Bulletin 141: 28-31.

Highton, R. (2000). Detecting cryptic species using allozyme data. The Biology of Plethodontid Salamanders. In :
R.C. Bruce, R.G. Jaeger, and L.D. Houck, eds., Kluwer Academic/Plenum Publishers, New York, 215-241.

Hime, P.M., Hotaling, S., Grewelle, R.E., O'Neill, E.M., Voss, S.R., Shaffer, H.B. \& Weisrock, D.W. (2016). The influence of locus number and information content on species delimitation: an empirical test case in an endangered Mexican salamander. Molecular ecology 25: 5959-5974.

IUCN, SSC Amphibian Specialist Group. (2015). Ambystoma ordinarium. The IUCN Red List of Threatened Species 2015: e.T59066A53974247. (http://dx.doi.org/10.2305/ IUCN.UK.2015-4.RLTS.T59066A53974247.en; assessed on 13 February 2019).

IUCN, SSC Amphibian Specialist Group. (2016). Ambystoma flavipiperatum. The IUCN Red List of Threatened Species 2016: e.T59056A3075883. (www.dx.doi.org/10.2305/ IUCN.UK.2016-1.RLTS.T59056A3075883.en; accessed on 10 January 2019).

Percino-Daniel, R., Recuero, E., Vázquez-Domínguez, E., Zamudio, K.R. \& Parra-Olea, G. (2016). All grown-up and nowhere to go: paedomorphosis and local adaptation in Ambystoma salamanders in the Cuenca Oriental of México. Biological Journal of the Linnean Society 118: 582-597.

Petranka, J.W. (1998). Salamanders of the United States and Canada. Smithsonian Institution Press. 592 pp.

Raffaëlli, J. (2013). Les Urodèles du monde. Edition Penclen. $480 \mathrm{pp}$.

Raffaëlli, J. \& Hernandez, A. (2019). La passion des Salamandres : le tour du monde des Urodèles en 80 histoires. Edition Penclen. 176 pp.

Rosas-Espinoza, V.C., García, M.E.S., Santiago-Pérez, A.L. \& Villarreal, J.M. (2014). Herpetofauna asociada a madrigueras de la tuza Pappogeomys bulleri en el bosque templado de Sierra de Quila, Jalisco. Revista Mexicana de Biodiversidad 85: 328-331.

Rosas-Espinoza, V.C., Rodríguez-Canseco, J.M., SantiagoPérez, A.L., Ayón-Escobedo, A. \& Domínguez-Laso, M. (2013). Distribution of some amphibians from central western México: Jalisco. Revista Mexicana de Biodiversidad 84: 690-696.

Santiago-Pérez, A.L., Domínguez-Laso, M., Rosas-Espinoza, V.C., Rodríguez-Canseco, J.M. (2012). Anfibios y Reptiles de las Montañas de Jalisco: Sierra de Quila. Orgánica Editores - Comisión Nacional para el Conocimiento y Uso de la Biodiversidad, Guadalajara, Mexico. 227 pp.

SEMARNAT 2010. Norma Oficial Mexicana NOM-ECOL-059SEMARNAT 2010. Protección Ambiental-Especies nativas de México de flora y fauna silvestres-categorías de riesgo y especificaciones para su inclusión, exclusión o cambio-lista de especies en riesgo. Diario Oficial de la Federación, 30 de diciembre del 2010.

Shaffer, H.B. (1984a). Evolution in a paedomorphic lineage. I. An electrophoretic analysis of the Mexican ambystomatid salamanders. Evolution 38: 1194-1206.

Shaffer, H.B. (1984b). Evolution in a paedomorphic lineage. II. Size and shape in the Mexican ambystomatid salamanders. Evolution 38: 1194-1206.

Shaffer, H.B. (1989). Natural history, ecology, and evolution of the Mexican "Axolotls". Axolotl Newsletter 18: 5-11. 
Shaffer, H. B. \& McKnight, M. L. (1996). The polytypic species revisited: genetic differentiation and molecular phylogenetics of the Tiger Salamander Ambystoma tigrinum (Amphibia: Caudata) complex. Evolution 50: 417-433.

Soto-Rojas, C., Suazo-Ortuño, I., Laos, J. A. M., \& AlvaradoDíaz, J. (2017). Habitat quality affects the incidence of morphological abnormalities in the endangered salamander Ambystoma ordinarium. Plos one 12 e0183573.

Taylor, J.D. (1940). New salamanders from Mexico, with a discussion of certain known forms. University of Kansas Science Bulletin: 26, 407-430.

Villers-Ruiz, L. \& Trejo-Vázquez, I. (2000). El cambio climático y la vegetación en México. México: una visión hacia el siglo XXI. El cambio climático en México. Instituto Nacional de Ecología. Universidad Nacional Autónoma de México, US Country Studies Program: 57-66.

Weisrock, D.W., Shaffer, H.B., Storz, B.L., Storz, S.R. \& Voss S.R. (2006). Multiple nuclear gene sequences identify phylogenetic species boundaries in the rapidly radiating clade of Mexican ambystomatid salamanders. Molecular Ecology 15: 2489-2503.

Accepted: 18 May 2019 